\title{
The Development of Project-Based Learning Training Module Online for Elementary School Teachers
}

\author{
Kurnia Setiawan ${ }^{1 *}$ Siti Nurannisaa ${ }^{1}$ Ninawati Ninawati ${ }^{2}$ Meiske Yunithree ${ }^{2}$ \\ ${ }^{I}$ Visual Communication Design, Faculty of Art and Design, Universitas Tarumanagara, Jakarta, Indonesia \\ ${ }^{2}$ Faculty of Psychology, Universitas Tarumanagara, Jakarta, Indonesia \\ *Corresponding author.Email: kurnias@fsrd.untar.ac.id
}

\begin{abstract}
Covid-19 pandemic changes many aspects in the world, including education sector. Teachers need to find some efforts to adapt and transform the following changes. It is necessary to choose the right approach to be applied in the teaching and learning process in schools, especially in basic education. From various models, one of which is project based learning (PBL) that is expected to help students to be more involved and understand learning better. There is a school in Surabaya that expects to implement PBL in teaching and learning activities for their students at the primary school level. Therefore, online PBL training is needed for school teachers before it is applied to students. How is the process of implementing online project based learning training for teachers carried out? How to develop teachers' creativity to be able to design interactive learning based on project based learning that will be held? The research conducted was descriptive qualitative. The research subjects were 24 teachers in Surabaya city, who would attend PBL training in October and November 2020. This research was participatory research because researchers were involved in the training activities that would be held. Based on the training process carried out, it turned out that there were some significant differences with respect to modules made for offline and online. The online module needed to be more detailed and complete. Resource persons needed to provide guidance (navigation), created a flow of time management and provided pauses for activities to keep participants focused and intense during the training. It took creativity from the speakers to make an attractive and quality presentation. The results of the research are expected to become a comprehensive study to create an online PBL training module that can be useful for scientific and community development
\end{abstract}

Keywords: Training, Project based learning, Creativity

\section{INTRODUCTION}

In Covid-19 pandemic situation, it gives impact to changing learning systems at various schools and levels of education. Home Learning or Distance Learning using an online system is a model of learning conducted in this situation. Various adjustments and changes continue to be made in an effort to find a distance learning model that fits learning needs. At the university level, they are familiar with the distance education model (PJJ) and the open university model, but this is different from education at the primary level. For example, home schooling (homeschooling) is the opposite of distance education. The pandemic situation is a challenge for the learning process at the elementary school level, even though elementary school is one of the levels of education that is the basis for developing character education. This level of education is not only intended for students to master the content/material, but should be a vehicle for educating them to grow and develop into human beings who are able to discover and develop their abilities. Learning can't be separated from the learning process. There are various learning models but which one is most suitable to be applied, especially in the Covid 19 pandemic situation? This is a big question for educators/teachers. One model that schools can do is to use project based learning or project-based learning. This learning provides the opportunity for teachers to manage learning through project creation. Projects contain complex tasks based on the questions and problems found and guide students to design, solve problems, make decisions, carry out investigative or investigative activities, center on the process and provide opportunities to work independently. Facing the challenge and online-based learning needs, additional support and training are needed to adapt to this new learning model. The introduction of a project based learning model can be used as an option in creating a student-centered learning environment and providing opportunities for the creation of a more interactive learning atmosphere. 
Research urgency: it gives support and the choice of project-based learning models with an online system, helps develop the creativity of teachers, thus, they can design more interactive learning, become a source of ideas and inspiration for teachers to make adjustments in the delivery of education with face-to-face learning methods (offline) to be online during a pandemic. The formulation of the research problem is How is the process of implementing online project based learning training online for teachers carried out? How to develop teachers' creativity to be able to design interactive learning based on problem based learning that will be held?

\section{BACKGROUND}

Project based learning or PBL requires students to solve problems or authentic or realistic learning activities. Learning helps students at the level of ability to think through a variety of questions and outlines the answers given. Therefore, project-based learning tends to have more flexible learning because of the opportunities for students to show what they find out. It provides students with alternatives and solutions for the problems they will face at a later date, encouraging active learning and a student-centered learning environment [1]. Project learning generates a solution-finding step scenario by identifying investigations, and describing ideas using a prototype in accordance with the project design. Students can present unique ideas for various problems, both social or technical proposed by the environment. The implementation of learning can be improved regularly for better creative thinking process education [2].

Technological changes occur because they are driven by human creativity to produce various creative works. With this reciprocal relation between creativity and technology, the teaching and learning process must be able to connect the two aspects. Educational practice requires a framework to assist students and teachers in developing skills to use technological tools for creative solutions and outcomes. The teacher's role in managing the class affects students' confidence in developing creativity. Creative teachers show their willingness to try new things, give assignments according to reality, and use an interdisciplinary approach. Creativity and effective technology in education must be considered systemically at three levels, as follow: teacher education level, education assessment and policy. This research presents implications and recommendations in these three areas, for building discourse around creative thinking and technology in the 21 st century education system [3]. [4] stated that there are seven characteristics of project learning such as: direct student involvement in learning, linking learning material with environmental realities, research-based, involving various learning resources, integrating knowledge and skills, through a process or duration of time stages, ends with the manufacture of certain products.

One of education problems is the lack of infrastructure. Thus, Teachers are required to be creative in improving the quality of classroom learning, such as developing instructional media. This research develops learning media for the game of snakes and ladders in social science learning (IPS) in elementary schools. Rifki Afandi, FKIP Muhammadiyah University Sidoarjo conducted a research entitled "Development of Learning Media for Snakes and Ladders to Increase Student Motivation and Social Studies Learning Outcomes in Elementary Schools, published in the Learning Innovation Journal. Vol. 1, No. 1, 2015. This research adopted the 4D model from the Thiagarajan, et al. Model such as define, design, develop, and dissaminate. Similar research was conducted in 2016 by the Primary School Study Program, Serang Campus, University of Education of Indonesia. The method used in this research was a concept analysis that was carried out by analyzing data in the form of existing concepts. The concept was analyzed based on the relation with other concepts or subjects to be studied, then developed and can produce a new concept or an existing concept that is more interesting and acceptable. The data were obtained from the results of document analysis, interviews and observations [5].

Training is the process of teaching the skills needed to conduct the job. Training is carried out in an effort to increase abilities or competencies, especially when faced with certain new jobs or situations. The objectives of the training [6] include the following: developing skills so that work can be completed more quickly and more effectively, developing knowledge so that work can be done optimally, developing attitudes in collaborating.

Project based learning $(\mathrm{PjBL})$ or project-based learning is a learning model that focuses on involving students in solving problems through project creation. Project-based learning, instruction is facilitated by the teacher as a facilitator in learning, but in the process ,it is carried out by the students themselves. Students explore their own knowledge through those sourced from their own natural curiosity [7]. Project-based learning steps train the development of the research process independently, explore and connect various information, and make decisions and assessments of things found through the project [8]. Project-based learning has the opportunity to produce deeper understanding of learning, thinking skills, and increasing learning motivation [7]. Projects that students work on can be in the form of individual or group projects and are carried out within a certain period of time, resulting in a product, which is then displayed or presented [9]. The benefits of this learning are to train students to be active and independent in making decisions to choose certain topics according to their abilities. The benefits of PBL according to [8] include the following: obtaining new knowledge and skills in learning, increasing ability in problem solving, building collaboration, students designing their own learning process, training to do selfevaluation, looking back at what has been done

The project needs to be designed according to the learning objectives. The teacher can adapt the project to the needs of teaching materials, thus, the skills used in the project match the learning objectives.

According to Fathurrohman [9] in general, the steps for a project-based learning model are as follows: 
1. Specifying the Project type

2. Planning for project completion steps

3. Preparation of project implementation schedule

4. Teacher-facilitated project completion

5. Preparation of reports and presentation or publication of project results

6. Evaluation of project processes and results

\section{METHODS}

The design of this research was qualitative descriptive. The research subjects were 24 elementary school teachers. The research would be carried out during the training by making observations and interviews. This research was conducted in Surabaya in October and November 2020. The research instruments used were: image and sound recording devices, writing equipment, and complementary needs. Data analysis was carried out by verbatim transcription for the results of research conducted based on observation, training evaluation questionnaires.

This research was conducted in the following activity stages.

1. Preliminary Stage. This stage was conducted to obtain information about the need for a learning model that is in accordance with the needs of the school level.

2. Development Stage was the stage of collecting information and developing training products. This stage consists of the training development stage, the validation stage and the development of training tools.

3. Evaluation Stage. This stage aimed to determine the quality assessment and learning outcomes carried out in the training.

4. Research Report Stage was arranging the process and research results in the form of a systematic report and formulating research for further research recommendations.

\section{FINDINGS AND DISCUSSIONS}

Covid-19 causes many changes in the world, including education sector. Teachers are looking for various efforts to adapt and transform based the changes that occur. Currently, teachers need to choose an appropriate approach in responding to changing situations to be applied in the teaching and learning process in schools, especially in basic education. The Ministry of Education and Culture on 19 September 2020 held a webinar entitled "Implementation of Project Based Learning during Distance Learning" that was attended by 11,000 viewers during broadcast and 40,000 viewers playback. The webinar presented 6 speakers ranging from education experts to teachers who had implemented PBL in their schools/classes. PBL was chosen as an appropriate learning method to be implemented in schools both in normal times and in current learning situations.

According to the Stamford Research Institute (2015 2016) involved 3000 schools and 100 teachers, ProjectBased Learning was able to increase motivation, problem solving abilities, better teacher-student interactions, in accordance with $21^{\text {st }}$ century learning; critical thinking, creativity, communication, collaboration, even students' math scores were 5 points higher.

Project-Based Learning has several principles as learning requirements below:

1. Student centered,

2. Themes taken from real life,

3. The execution of tasks results in a specific product,

4. The process is monitored and evaluated by the teacher.

Project-Based Learning had various types of stages, starting from $4,5,6,7$, to 8 . One of the most commonly used pathways was 6 stages:

1. Arranging basic questions (teachers and students formulate questions/explore ideas for something they want to learn / do),

2. Designing a project plan.

3. Making a schedule,

4. Monitoring,

5. Testing results,

6. Evaluation.

Project-Based Learning makes students have engagement with a meaningful project. Thus, they are able to learn at a deeper level. With regard to the need for Project-Based Learning (PBL) training for teachers in October and November 2020 which would be held online in 8 meetings with a duration of 2 hours/session, a training module was compiled in 3 stages, such as introduction, preparation, and PBL implementation. The training carried out would apply PBL practically, in which the teachers would process (involve themselves) in compiling PBL (as a project), implement, present, end with evaluation and reflection together

Project Based Learning (PBL) Training Modules:

1. Introduction + self-knowing and others,

2. Built-in Learning Styles

3. PBL philosophy,

4. Basic Principles and Stages of PBL,

5. PBL Activity Planning 1

6. PBL 2 Activity Planning,

7. PBL 3 Activity Planning,

8. PBL Activity Planning 4.

In PBL activity planning 8th sesssion the participant fill in the PBL teacher worksheet. The worksheet summaries the PBL into 4 steps :

1. Project plan (including entry event and driving question) Theme, Project, Equipment, Schedule.

2. Monitoring

3. Presentation

4. Evaluation and Reflection

Participants will implement the PBL teacher workseet as a result from PBL online Training. 
Table 1 Online PBL Training Participants

\begin{tabular}{|c|l|l|}
\hline No & \multicolumn{1}{|c|}{ Nama } & \multicolumn{1}{|c|}{ Jabatan } \\
\hline 1 & Lim Tien & Kepala Sekolah \\
\hline 2 & Trisuta Ngudi Raharia & waka kurikululum \\
\hline 3 & Budi Sulistyani & PJ Jenjang \\
\hline 4 & Wong Milka & PJ Jenjang \\
\hline 5 & Bunga Dewanti & Ketua mapel Math \\
\hline 6 & Yohana Intan & Guru \\
\hline 7 & Isa Lesmana & Guru \\
\hline 8 & Lily Tjahjani & Kepala Sekolah \\
\hline 9 & Chrissie Evert & waka kurikulum \\
\hline 10 & Dita Kumala Dewi & PJ Jenjang \\
\hline 11 & Isliana Rukminingsih & PJ Jenjang \\
\hline 12 & Mamik Sri Hartatik & Ketua mapel Math \\
\hline 13 & Ony Wahyudiantaro & Guru \\
\hline 14 & Mutiara Sekar Utami & Guru \\
\hline 15 & Silvana Charla & Kepala Sekolah \\
\hline 16 & Ita Ariesta & waka kurikulum \\
\hline 17 & Ratna & PJ Jenjang \\
\hline 18 & Christina Natalia & PJ Jenjang \\
\hline 19 & Indyah Christmasttuti & PJ Jenjang \\
\hline 20 & Andreas Armando & PJ Jenjang \\
\hline 21 & Sapto Karjunita & Ketua Mapel Math \\
\hline 22 & Boedi Handajani & Guru/waka sarpras \\
\hline 23 & Angela Wijaya & \\
\hline 24 & Esther Marpaung & \\
\hline & & \\
\hline
\end{tabular}

Source: Personal Documentation

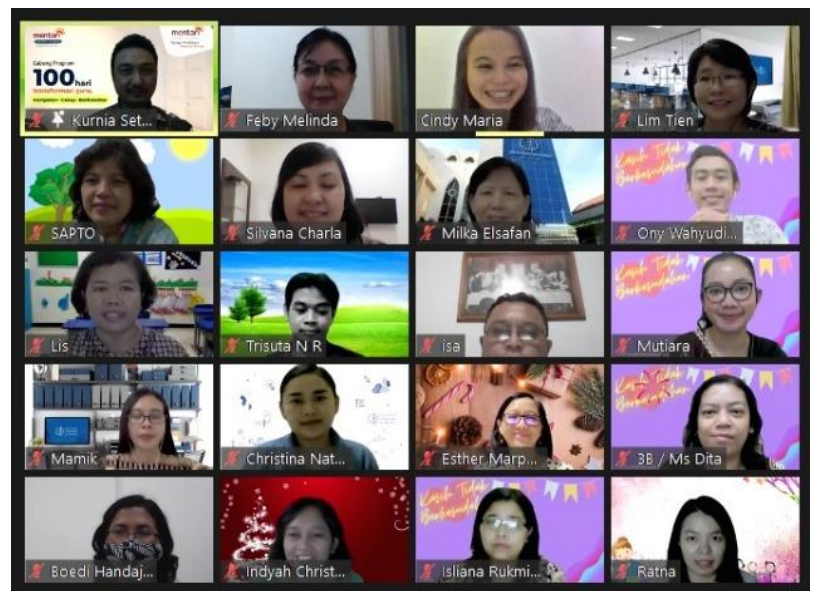

Figure 1 PBL Workshop Participants

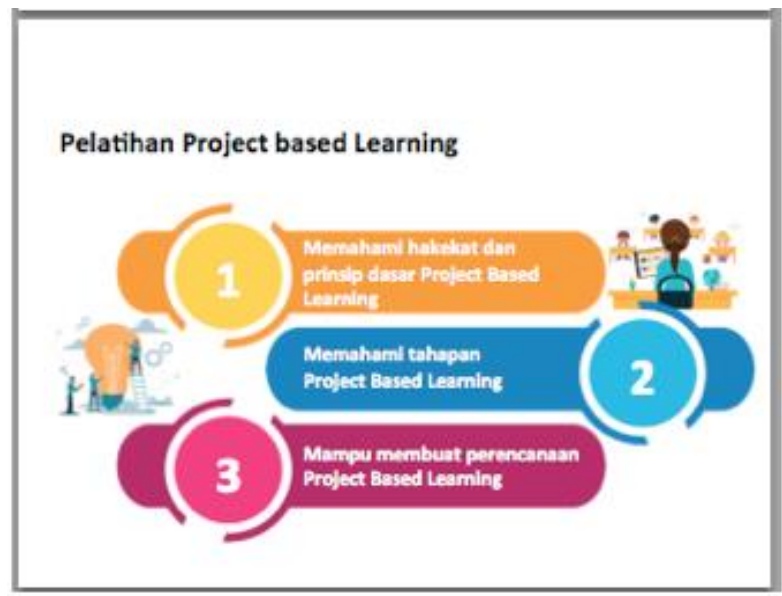

Figure 2 PBL Module

During the training, navigation tools play impotrance role to guide workshop participants. In the beginning, trainer didn't use the nagiation and then based on review and evaluation from the previous session, trainer improved presenttation methods with navigation and use some tools from digital application platform, such as breack out room and padlet. The quality of workshop improved gradualy. Participants fill in the quessionare after each session. Hopefully, the feedback from participants about the PBL workshop very positives. PBL training help them to understand more deeply about PBL so they can implement PBL methods better in 2021 in their school. Before PBL workshop teachers used PBL in they classroom with some doutb becauce they do not have sufficient knowledge about the PBL.

From researcher perspective as trainer in PBL training, there's some improvement in teaching methods in online training that very different from offline training. There's a differenet circumstances have to calculate. The preparation have a important role especialy Power Point Presentation (PPT). Trainer also have to arrange the schedule more specific than in offline training. The biggest challenge in online training is to maintain participant attetion with some activity or interaction. 


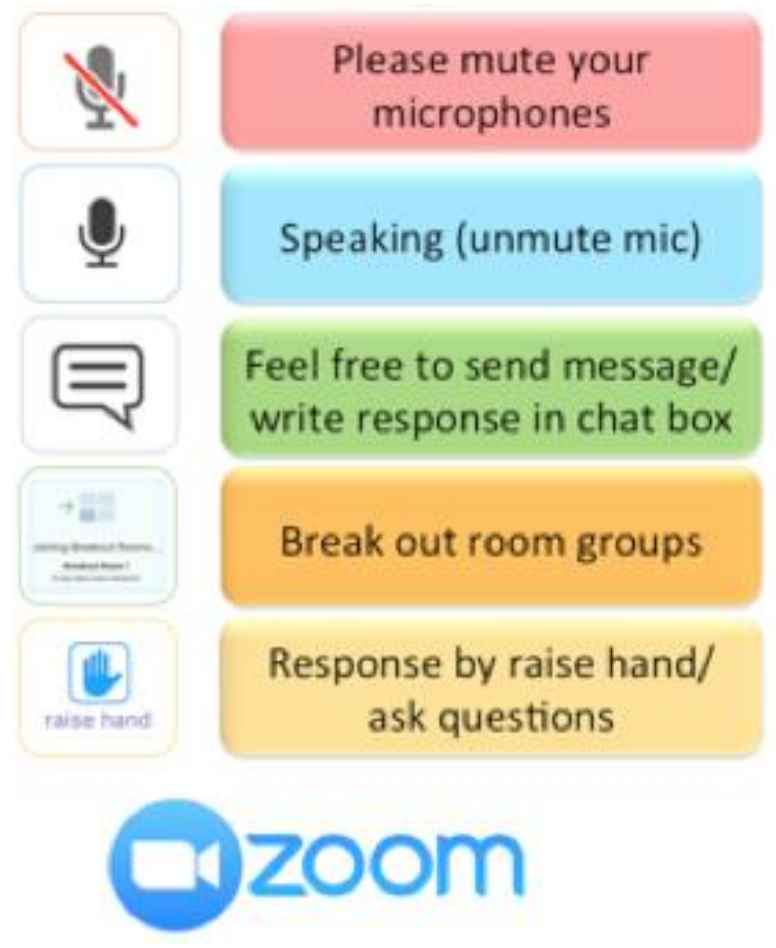

Figure 3 Navigation Tools

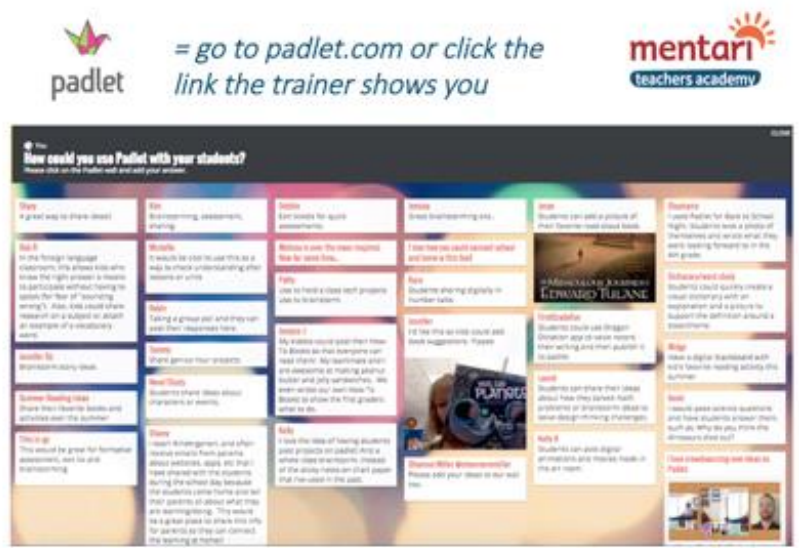

Figure 4 Padlet Tools

\section{CONCLUSIONS}

Project Based Learning (PBL) training for teachers was conducted in 8 sessions of 2 hours meeting in October and November 2020. The preparation of training modules and worksheets at the beginning of the training apparently need to be changed at the time of realization, adjusted to the needs of online training. Planning in more detail is about flow, time, methods, and materials. Therefore, participants focus and pay attention during the session. Several things need to be conducted as follow;

1. Making navigation on ppt and explain it at the beginning of the session,
2. Providing a pause in the activity so that participants don't get bored,

3. Setting a certain duration of time for each activity,

4. Optimizing digital features,

5. Maintain interaction with participants.

The development of an online Project Based Learning training module needs to pay more attention to the context, not just focus on the content to be delivered so that the training can be followed by participants optimally. Suggestions are about the current situation, PBL modules can be used not only for elementary school students, but also middle and advanced level students, even college students. Teachers need to understand the context and learn various learning methods that are appropriate to use, especially in a covid 19 pandemic situation.

\section{ACKNOWLEDGMENT}

Researchers give their gratitude to Mentari Teacher Academy, Schools in Surabaya, as well as to the Tarumanagara University Research and Community Service Institute (LPPM).

\section{REFERENCES}

[1] Jumaat, N. F., Tasir, Z., Abd halim, N. D., \& Ashari, Z. M. 2017. Project-Based Learning from constructivism point of view. Advanced Science Letters Vol, 23 (8), 1-4.

[2] Sun K. Kim, Kurt Beiter, Olivier Ladislas de Weck. 2013. A New Project-Based Curriculum of Design Thinking with Systems Engineering Techniques. International Journal of System of Systems Engineering.

[3] Henriksen, D., Mishra, P., \& Fisser, P. 2016. Infusing creativity and technology in 21 st century education: A Systemic view for change. Educational Technology \& Society, 19 (3), 27-37.

[4] Diffily, D., \& Sassman, C. (2002). Project-based learning with young children.

[5] Estiyani, Vinny Fuji, Ajo Sutarjo, Denii Wardana. (2016). Modifikasi Permainan Ular Tangga Sebagai Alternatif Media Pembelajaran Penjumlahan dan Pengurangan Bilangan Bulat. Jurnal Kalimaya, 4 (2). 
[6] Moekijat. 1991. Evaluasi Pelatihan Dalam Rangka Peningkatan Produktivitas. Mandar Maju. Bandung.

[7] Bell, S. (2010). Project-Based Learning for the 21st century: Skills for the future. The Clearing House, 83, 39-43.

[8] Aldabbus, S. (2018). Project-Based learning: Implementation \& challenges. International Journal of Education, Learning and Development, 6, (3), 71-79.

[9] Fathurrohman, M. (2015). Model-Model Pembelajaran Inovatif. Yogyakarta: Ar-Ruzz Media. 